ЛЕСОЭКСПЛУАТАЦИЯ

УДК: $630 * 311(470.1 / .2)$

DOI: $10.37482 / 0536-1036-2021-5-92-116$

\title{
METHODS OF PROTECTION FOREST SOILS DURING LOGGING OPERATIONS (REVIEW)
}

\author{
Aleksey S. Ilintsev', Candidate of Agriculture, Senior Research Scientist; \\ ResearcherID: N-6286-2019, ORCID: https://orcid.org/0000-0003-3524-4665 \\ Elena N. Nakvasina ${ }^{2}$, Doctor of Agriculture, Prof.; ResearcherID: A-5165-2013, \\ ORCID: https://orcid.org/0000-0002-7360-3975
}

Lars Högbom 3,4, PhD, Associated Professor; ORCID: https://orcid.org/0000-0002-6914-2897

${ }^{1}$ Northern Research Institute of Forestry, ul. Nikitova, 13, Arkhangelsk, 163062, Russian

Federation; e-mail: a.ilintsev@narfu.ru

${ }^{2}$ Northern (Arctic) Federal University named after M.V. Lomonosov, Naberezhnaya Severnoy

Dviny, 17, Arkhangelsk, 163002, Russian Federation; e-mail: e.nakvasina@narfu.ru

${ }^{3}$ Skogforsk - The Forestry Research Institute of Sweden, Uppsala Science Park, Uppsala, SE-751 83, Sweden; e-mail: lars.hogbom@skogforsk.se

${ }^{4}$ Swedish University of Agricultural Sciences, Umeå, 901 03, Sweden;

e-mail: lars.hogbom@slu.se

Review article / Received on March 1, 2020 / Accepted on May 10, 2020

\begin{abstract}
Public opinion has become increasingly critical of current logging methods and technologies, and there is a demand for standards to guide the operations of environmentally impactful industries. For many years, numerous researchers have studied the impact of logging on forest soils, revealing that there is a high risk of damaging forest soil during forest operations and terrain transport. Here we analyse and review a total of 105 publications in this area. This large body of work demonstrates the scientific interest that this field has attracted. Despite this, important areas of uncertainty concerning the impact of forest harvesting still remain. In particular, changes in soil conditions can affect soil properties in ways that are not well understood, with possible impacts on the physical, chemical, and biological properties of soils as well as the structure of the soil cover. While it is difficult to fully eliminate the negative impact of forest operations on forest soils, their adverse environmental consequences should be minimised because soil plays a vital role in tree regeneration and helps determine the productivity of future forest stands. Some of the most frequently cited measures and effective technological solutions to minimize damage to forest soils involve taking terrain and different technical solutions into account when organising logging operations. Potentially helpful technical solutions include selecting machines and mechanisms suitable for the site conditions, using larger and/or low-pressure tyres, using tyre pressure control, using anti-skid tracks, using track belts, meliorating wet areas, and using logging machinery incorporating global positioning systems and geographic information systems. Planning measures that can help minimize soil damage include choosing a suitable wood harvesting system and technology, accounting for seasonal factors when planning logging operations, planning networks of roads and trails in advance, leaving wood residues or mats on soil surface, training forest specialists, and reducing the number of machine passes over skid trails and strip roads.
\end{abstract}

This is an open access article distributed under the terms of the Creative Commons Attribution 4.0 International (CC BY 4.0) license - The authors declare that there is no conflict of interest 
Despite active interest in applying sparing methods of wood harvesting, uptake of measures designed to reduce negative impacts on forest soils after logging has been limited. This may be due to a lack of scientific and technical information and the high cost of implementing best management practices. Moreover, economic factors and production plans may require wood harvesting throughout the year, irrespective of conditions.

For citation: Ilintsev A.S., Nakvasina E.N., Högbom L. Methods of Protection Forest Soils during Logging Operations (Review). Lesnoy Zhurnal [Russian Forestry Journal], 2021, no. 5, pp. 92-116. DOI: 10.37482/0536-1036-2021-5-92-116

Funding: The research was financially supported by the Ministry of Science and Higher Education of the Russian Federation as part of the project "Patterns of Changes in the Forest Site Environment under the Influence of Anthropogenic Factors (Logging) in the Boreal Forests of the North" No. MK-2622.2021.5. Part of the research was carried out within the framework of the state assignment of the Northern Research Institute of Forestry (No. 121020500252-6).

Keywords: forest ecosystems, soil, anthropogenic load, logging, forest machinery, ecological consequences, progressive succession, best practices.

\title{
СПОСОБЫ ЗАЩИТЫ ЛЕСНЫХ ПОЧВ В ХОДЕ ЛЕСОЗАГОТОВИТЕЛЬНЫХ РАБОТ (ОБЗОР)
}

\author{
А.С. Ильинцев ${ }^{1}$ канд. с.-х. наук, ст. науч. сотр.; ResearcherID: N-6286-2019, \\ ORCID: https://orcid.org/0000-0003-3524-4665 \\ E.Н. Наквасина ${ }^{2}$, д-р с.-х. наук, проф.; ResearcherID: A-5165-2013, \\ ORCID: https://orcid.org/0000-0002-7360-3975 \\ Л. Хогбом 3 ,, PhD, доц.; ORCID: https://orcid.org/0000-0002-6914-2897 \\ ${ }^{1}$ Северный научно-исследовательский институт лесного хозяйства, ул. Никитова, д. 13, \\ г. Архангельск, Россия, 163062; e-mail: a.ilintsev@narfu.ru \\ ${ }^{2}$ Северный (Арктический) федеральный университет им. М.В. Ломоносова, наб. Север- \\ ной Двины, д. 17, г. Архангельск, Россия, 163002; e-mail: e.nakvasina@narfu.ru \\ ${ }^{3}$ Научно-исследовательский институт лесного хозяйства Швеции, Научный парк Уппса- \\ ла, г. Уппсала, Швеция, SE-751 83; e-mail: lars.hogbom@skogforsk.se \\ ${ }^{4}$ Шведский университет сельскохозяйственных наук, г. Умео, Швеция, 901 03; \\ e-mail: lars.hogbom@slu.se
}

Обзорная статья / Поступила в редакичию 01.03.20 / Принята к печати 10.05.20

Аннотация. Отношение общественности к вопросу экологичности лесозаготовительных методов и технологий заготовки древесины становится все более критичным. Анализ 105 публикаций, включенных в данный обзор, показывает, что подобные исследования вызывают интерес у ученых всего мира. За длительный период изучения обозначенной проблемы накопилось много работ о влиянии рубок леса на лесные почвы. Однако, как отмечают специалисты, эти знания еще не являются полными. На вырубках вследствие движения машин во время выполнения технологических операций появляются различные повреждения грунта. Изменения условий почвообразования в той или иной степени отражаются на всех свойствах почвы: физических, химических и биологических - а также на структуре почвенного покрова. Полностью исключить воздействие лесозаготовительной техники на лесные почвы невозможно, но свести к минимуму необходимо. Наиболее часто указываемые и эффективные технологические решения по ограничению негативных последствий прохода лесной техники это: проведение лесозаготовительных работ с учетом природных факторов; выбор систе-

Данная статья опубликована в режиме открытого доступа и распространяется на условиях лицензии Creative Commons «Attribution» («Атрибуция») 4.0 Всемирная (СС ВY 4.0) • Авторы заявляют об отсутствии конфликта интересов 
мы заготовки древесины; планирование сезона лесозаготовок, методов лесосечных работ, технологической сети; оставление порубочных остатков на поверхности почвы; дополнительное обучение специалистов, работающих в лесу; подбор системы машин и механизмов; снижение количества проездов техники по технологическим волокам; использование шин большего размера и низкого давления, системы управления давлением в шинах; применение цепей противоскольжения, гусеничных лент; проведение мелиорации влажных участков; установка систем GPS и GIS в лесозаготовительной технике. Несмотря на активный интерес к щадящим методам заготовки древесины, меры, направленные на сохранение лесных почв после осуществления лесозаготовительных работ, приняты в недостаточном объеме. Причинами могут быть неполнота научно-технической информации и высокая стоимость внедрения передовой практики управления. Кроме того, экономические факторы и производственные планы требуют заготовки древесины в течение всего года и не принимают в расчет неблагоприятные погодные условия.

Для цитирования: Ilintsev A.S., Nakvasina E.N., Högbom L. Methods of Protection Forest Soils during Logging Operations (Review) // Изв. вузов. Лесн. журн. 2021. № 5. C. 92-116. DOI: 10.37482/0536-1036-2021-5-92-116

Финансирование: Работа выполнена при финансовой поддержке Министерства науки и высшего образования Российской Федерации в рамках проекта МК-2622.2021.5 «Закономерности изменения лесорастительной среды под влиянием антропогенных факторов (рубок леса) в бореальных лесах Севера». Часть исследования проведена в рамках государственного задания ФБУ «СевНИИЛХ» (№ 121020500252-6).

Ключевые слова: лесные экосистемы, почва, антропогенная нагрузка, рубки леса, лесозаготовительная техника, экологические последствия, восстановительная сукцессия, лучшие практики.

\section{Introduction}

Forestry management and forest operations have become controversial due to fundamental differences in the ways different segments of society view forest resources. Public attitudes towards forest management and logging technologies have become more critical, and there is a growing demand for environmentally impactful industries to act in accordance with the standards of organisations such as the Forest Stewardship Council (FSC) or Programme for the Endorsement of Forest Certification (PEFC). It is therefore important to account for environmental concerns during logging activities, not least those relating to effects on soil and water [15]. Forest soils are vital for ecosystem productivity and the sustainability of ecosystem services [10, 41, 98].

The use of heavy logging machines (e.g. harvesters, fellers, skidders, and forwarders) during logging operations presents a high risk of damaging the soil surface. The masses of forest machines range from 5-40 t [24, 46], and these masses exert direct pressure on the soil surface in contact with the machine. Soil surface damage occurs when the specific pressure of the active system of machines exceeds the soil's load-bearing capacity. According to Cambi et al. [15], the use of powerful and heavy machines in forestry has increased exponentially in recent decades. Additionally, not all machines used in logging operations meet environmental requirements; most logging enterprises in Russia today have out-dated fleets of logging machines [73].

The impact of logging on the properties of forest soils has been studied for many years. Despite this, both Russian scientists $[19,82]$ and researchers from other countries $[15,63]$ have noted that our understanding of the impact of logging on soils 
is incomplete for two reasons: the technology and techniques of logging operations are changing and the impact of logging operations is being affected by climate change and abnormal weather conditions [87].

Sustainable forest management and ways of reducing the impact of logging have attracted growing interest in recent years, prompting efforts to develop sparing (nature-saving) methods of logging, design new logging machines, and revise the technological processes used in forestry [37].

While the impact of logging equipment on forest soils cannot be completely eliminated, there are ways to limit it [63]. Accordingly, various solutions have been proposed to limit or minimise the impact of logging machinery on forest ecosystems. Successful implementation of any solution will require deep knowledge and understanding of several topics relevant to logging activities and their impact (including forest soil science, plant physiology, forest ecology, silviculture, and machines and mechanisms) in order to calibrate measures based on the durability of the forest environment and its susceptibility to damage. Decisions about what logging equipment and technology to use should be based on detailed knowledge of the soil properties in the forest to be logged and an assessment of environmental risks.

This article reviews the literature on preventing or limiting negative impacts of mechanised logging on soil in order to provide guidance on minimising the negative impact of logging machinery on soil and thereby promote sustainable forest management.

\section{Prerequisites for reducing the impact of logging on the soils}

The historical progress of logging technology can be divided into four stages. This section briefly reviews the equipment and methods used during logging operations in each stage as well as their impact on forest soils [97].

The first stage (from the 15th to the early 20th century) is associated with the exploitation of the European North of Russia [99], during which key forestry activities included salt-making, the production of charcoal and tar, and household wood harvesting. Throughout this period, logging was done exclusively by hand in winter, and wood removal (skidding) was done by horse-drawn transport over short distances. Axes and saws were the main tools for felling trees, and logging was performed according to a simple selective strategy without territorial restrictions. The combination of winter logging and horse skidding helped to preserve the forest environment and minimise adverse impacts on the soil.

The second stage (1930-1970) is associated with the early development of the logging industry and the introduction of mechanized skidders such as the S-60, KT-12, S-80, TL-3, TDT-4, and TT-4 models [97]. Forced-selective and narrow-cut logging strategies were replaced by the cut block approach. Haphazard skidding over huge cutting areas contributed to changes in breed composition and worsened the environmental conditions of the resulting cuttings. In the Nordic countries (particularly in Sweden), forestry machines were introduced on a large scale in the 1960s [26]. Since then, soil damage has become a significant problem worldwide [23]. Machines such as agricultural tractors were used for many tasks during logging operations, including harvesting and hauling wood. However, they were often unsuitable for these purposes [102]. 
During the third stage (which began in 1970), heavy machines for domestic production were introduced. The appearance of machines such as fellerbunchers (e.g. the Timberjack 850, LP-19), the VTM-4 felling-skidding machine and the LP-18 and LT-154 lockless skidders increased labour productivity but also caused significant damage to the top soil. When developing LP-19 cutting areas, skid trails were not defined in advance, trees were skidded forward, and the cutting areas were completely covered by skid trails because of the limited reach of the machine's hydraulic manipulator [86]. The resulting environmental damage clearly demonstrated the challenges of preserving the forest environment during logging. The machines used in most cases did not meet environmental requirements and exerted specific pressures significantly greater than $50 \mathrm{kPa}$ on the soil [37].

Pobedinskiy [79] and Gusev et al. [37] noted that in some cases, the changes in the forest environment caused by logging operations using forest machines are more significant than those associated with forest removal.

The fourth stage is the present and near future. New systems of machines for logging (harvesters and forwarders) have been introduced and begun replacing felling and bunching machines, but this has not been a positive change in terms of soil conservation [24,97]. One way to overcome the problems caused by forest machines is to use smaller and more manoeuvrable tractors and multi-operation (combined) machines. In modern forestry there are specialised machines for almost all activities, including soil preparation, sowing, planting, care felling, thinning, and transportation. Modern machines are small and better suited for tasks such as thinning than those that were available in the early years of mechanisation [102]. In addition, new state-of-the-art machines and information tools are being introduced that can help reduce negative impacts on soils and increase the efficiency of logging machines.

\section{Changes in soil properties after logging operations}

Harvesting operations cause various forms of damage to the soil, including compaction, soil mixing, and the formation of turned-over, bared, and loosened sites. Such damage can lead to changes in biogeochemical cycles [15] and the development of hydrological shortcuts [86].

Changes in soil formation conditions affect all soil properties to some degree (table 1), including physical, chemical, and biological properties as well as the structure of the soil cover $[19,76,80,103,105]$. Many authors $[2,5,11]$ have noted that compaction caused by forest operations is a major cause of soil degradation.

\section{Changes in physical properties}

The main effect of logging operations on soils is compaction, which can be quantified by measuring the soil's bulk density or hardness (resistance to penetration). It is believed that soil compaction caused by logging is most severe at a depth of $10 \mathrm{~cm}$, with less pronounced effects at $20 \mathrm{~cm}$ and $30 \mathrm{~cm}$ [2]. For example, noticeable changes in physical properties are observed at portages to depths of 50-60 cm and at landing sites to a depth of $90 \mathrm{~cm}$ $[20,45]$. Changes in the density of the soil and the associated effects on air, heat, and water regimes affect soil organisms and plants and can also have negative effects on the ecological state of soils and future forest productivity $[15,52,68]$. 
Table 1

Effects of logging operations on the soil cover

\begin{tabular}{|c|c|}
\hline $\begin{array}{l}\text { Type and direction } \\
\text { of the impact }\end{array}$ & Authors \\
\hline \multicolumn{2}{|r|}{ Structure of the soil cover } \\
\hline $\begin{array}{l}\text { Mixing and } \\
\text { removing horizons } \\
\approx \neq\end{array}$ & $\begin{array}{l}\text { Kozlowski, } 1999 \text { [52]; Melekhov, } 2003 \text { [69]; Dymov, Lapteva, } 2006 \\
\text { [20] }\end{array}$ \\
\hline $\begin{array}{l}\text { Rut formation } \\
\downarrow \leftrightarrow \neq\end{array}$ & $\begin{array}{l}\text { Jansson, Johansson, } 1998 \text { [45]; Lacey, Ryan, } 2000 \text { [56]; Eliasson, } \\
2005 \text { [24]; Dymov, Lapteva, } 2006 \text { [20]; Eliasson, Wästerlund, 2007 } \\
\text { [25]; Gerasimov, Katarov, } 2010 \text { [33]; Katarov et al., 2013 [50]; } \\
\text { Marchi et al., 2014 [64]; Cambi et al., 2015 [15]; Goltsev et al., 2011 } \\
\text { [35]; Sirén et al., } 2019 \text { [87]; Garren et al., } 2019 \text { [31]; Ilintsev et al., } \\
2020 \text { [42] }\end{array}$ \\
\hline \multicolumn{2}{|r|}{ Physical properties of the soils } \\
\hline Compaction $\downarrow \leftrightarrow$ & $\begin{array}{l}\text { Seryy et al., } 1991 \text { [86]; Jansson, Johansson, 1998 [45]; Kozlowski, } 1999 \\
\text { [52]; Brais, } 2001 \text { [11]; Sušnjar et al., } 2006 \text { [93]; Dymov, Lapteva, } 2006 \\
\text { [20]; Akay et al., 2007 [2]; Magnusson, } 2009 \text { [62]; Gerasimov, Katarov, } \\
2010 \text { [33]; Frey et al., 2009 [30]; Bagheri et al., 2011 [5]; Goltsev et al., } \\
2011 \text { [35]; Pobedinskiy, } 2013 \text { [79]; Bottinelli et al., 2014 [9]; Cambi } \\
\text { et al., 2015 [15]; Ilintsev et al., } 2020 \text { [42]; Mariotti et al., } 2020 \text { [66] }\end{array}$ \\
\hline $\begin{array}{l}\text { Water-air regime } \\
\downarrow \leftrightarrow\end{array}$ & $\begin{array}{l}\text { Seryy et al., } 1991 \text { [86]; Wronski, Murphy, } 1994 \text { [104]; Kozlowski, } \\
1999 \text { [52]; McNabb et al., 2001 [68]; Magnusson, 2009 [62]; Han } \\
\text { et al., } 2006 \text { [38]; Dymov, Lapteva, 2006 [20]; Cambi et al., 2015 [15] }\end{array}$ \\
\hline $\begin{array}{l}\text { Thermal condition } \\
\uparrow \leftrightarrow\end{array}$ & Arnup, 1998 [4]; Dymov, Startsev, 2016 [22] \\
\hline \multicolumn{2}{|r|}{ Chemical properties of the soils } \\
\hline $\begin{array}{l}\text { Nutritional } \\
\text { regime and } \\
\text { biogeochemical } \\
\text { cycles } \downarrow \leftrightarrow\end{array}$ & $\begin{array}{l}\text { Worrell, Hampson } 1997 \text { [103]; Zetterberg, } 2013 \text { [105]; Naghdi et al. } \\
\text { 2016 [75]; Modry, Hubeny, 2003 [71]; Hume et al, } 2017 \text { [41]; Cambi } \\
\text { et al., } 2017 \text { [16]; Ilintsev et al., } 2018 \text { [43]; Ilintsev et al., } 2020 \text { [42] }\end{array}$ \\
\hline $\begin{array}{l}\text { Balance and } \\
\text { composition of } \\
\text { organic matter } \downarrow \leftrightarrow\end{array}$ & $\begin{array}{l}\text { Fedchenko, } 1962 \text { [27]; Varfolomeev, } 1964 \text { [100]; Fedorets, Bakhmet, } \\
2003 \text { [29]; McLaughlin, Phillips, } 2006 \text { [67]; Dymov, Lapteva, } 2006 \\
\text { [20]; Sah, Ilvesniemi, } 2007 \text { [84]; Vedrova et al., } 2010 \text { [101]; Osman, } \\
2013 \text { [76]; Dymov, Milanovskii, } 2014 \text { [21]; Dymov, } 2017 \text { [19]; } \\
\text { Dolgaya, Bakhmet, } 2021 \text { [18] }\end{array}$ \\
\hline Soil acidity $\downarrow \leftrightarrow$ & $\begin{array}{l}\text { Seryy et al., } 1991 \text { [86]; Brandtberg, Olsson, } 2012 \text { [12]; Dymov, } \\
\text { Milanovskii, } 2014 \text { [21]; Achat et al., } 2015 \text { [1]; Ilintsev et al., 2018 [43] }\end{array}$ \\
\hline \multicolumn{2}{|r|}{ Biological properties of the soils } \\
\hline $\begin{array}{l}\text { Composition and } \\
\text { activity of soil } \\
\text { organisms } \downarrow \leftrightarrow\end{array}$ & $\begin{array}{l}\text { Seryy et al., } 1991 \text { [86]; Li et al., } 2004 \text { [60]; Battigelli et al., } 2004 \text { [6]; } \\
\text { Mariani et al., } 2006 \text { [65]; Frey et al., 2009 [30]; Beylich et al., } 2010 \\
\text { [7]; Blasi et al., } 2013 \text { [8]; Bottinelli et al., } 2014 \text { [9]; Cambi et al., } \\
2015 \text { [15]; Dymov, Startsev, } 2016 \text { [22] }\end{array}$ \\
\hline \multicolumn{2}{|r|}{ Regeneration conditions } \\
\hline $\begin{array}{l}\text { Seed germination } \\
\text { and plant growth } \\
\approx \leftrightarrow\end{array}$ & $\begin{array}{l}\text { Sokolovskaya et al., } 1977 \text { [88]; Seryy et al., 1991 [86]; Dymov, } \\
\text { Lapteva, } 2006 \text { [20]; Sušnjar et al. } 2006 \text { [93]; Karpechko, 2008 [48]; } \\
\text { Gebauer et al., 2012 [32]; Hattori et al., } 2013 \text { [39]; Fedorenchik et } \\
\text { al., } 2013 \text { [28]; Cambi et al., } 2017 \text { [16]; Solgi et al., 2019 [90]; Ilintsev } \\
\text { et al., } 2020 \text { [42] }\end{array}$ \\
\hline
\end{tabular}

Note: Decline $-\downarrow$; unknown $-\approx$; improvement $-\uparrow$; recovery over time $-\leftrightarrow$; persistent disturbances $-\neq$. 
For example, a common cause of poor plant growth is a reduction in the levels of plant-available nutrients $[9,15,30]$. Increasing the bulk density of the soil reduces its pore size, water permeability, and gas exchange rates, which in turn reduces the available moisture content. All these factors affect root system formation and plant growth $[66,93]$.

An increase in the soil's water content implies a decrease in the friction forces between the soil particles, which reduces the load-bearing capacity of the soil $[38,68]$. Studies by various authors have shown that restriction of nutrient and water access affects the germination rate, root mass, root length, and main stem height of plants $[16,48,66,89]$. The negative effects of compaction of the upper soil horizons on root biomass have been observed over a 15 -year period [48].

Soil compaction also changes the water-physical properties of the soil in clearings with heavy podzolic loamy and clay soils [79]. The compaction characteristics of a soil depend on its particle size, humidity, and organic matter content; some are stable, while others are less stable. Sandy loam and sandy soils are less compacted by logging machinery. The negative effect of soil bulk density depends on the soil's particle size distribution: the greater the abundance of large particles, the worse the impact of high bulk density on plant growth.

Studies on tree seedlings [86] show that the main mass of the roots of eight-yearold crops on skid trails is located at depths of up to $10 \mathrm{~cm}$, and up to $14 \mathrm{~cm}$ in cutting strips. Additionally, spruce seedlings growing in the cutting strips have significantly more fine roots than those in the strips, and spruce seedlings growing on compacted soil exhibit reduced height and diameter growth as well as canopy development when compared to peers grown on non-compacted soil. The available data indicate that the compaction of sandy soils to densities of up to $1.5 \mathrm{~g} / \mathrm{cm}^{3}$ during logging has a positive effect on the survival of seedlings following both sowing and planting. However, pine and spruce seedlings planted on compacted loamy soils exhibit low survival rates and poor growth, indicating a need to improve the physical properties of such soils by loosening before regeneration. Melekhov [69] notes that in some cases compaction and mixing of the soil's organic and mineral components can be very important for improving the growth of young plants. Loosening of fresh soils without compaction can reduce the capillary lift. Additionally, Dymov and Lapteva [20] conclude that removing the plant cover and the forest floor horizon reduces seed germination by $15-28 \%$ because it disrupts the main organogenic horizon in podzolic soils, where significant reserves of energy and plant nutrition elements accumulate.

According to Sokolovskaya et al. [88], the germination of spruce seeds in loamy soils is clearly hindered when the soil density exceeds $1.45 \mathrm{~g} / \mathrm{cm}^{3}$. The optimal soil bulk density for successful spruce growth was $1.15-1.28 \mathrm{~g} / \mathrm{cm}^{3}$; compaction to densities of 1.30-1.34 g/ $\mathrm{cm}^{3}$ and above reduced the growth rates of young seedlings. Similarly, Seryy et al. [86] found that the optimal bulk density for seedling growth is $1.0-1.3 \mathrm{~g} / \mathrm{cm}^{3}$ and depends on the soil's particle size. For comparative purposes, the upper soil horizons $(0-25 \mathrm{~cm})$ on landing sites and main skid trails are compacted to $1.7-1.87 \mathrm{~g} / \mathrm{cm}^{3}$. These bulk soil densities significantly exceed the critical compaction level of $1.4 \mathrm{~g} / \mathrm{cm}^{3}$; above this threshold, the soil's ability to self-heal and recover its original density is weakened or completely lost. However, as reported by Kuznetsova and Danilova [53] each soil type has a distinct critical compaction threshold. Hattori et al. [39] also note that changes in soil bulk density can increase seedling mortality, while Fedorenchik et al. [28] found that root growth stops when the soil bulk density 
exceeds $1.89 \mathrm{~g} / \mathrm{cm}^{3}$ for oak, $1.84 \mathrm{~g} / \mathrm{cm}^{3}$ for larch, $1.80 \mathrm{~g} / \mathrm{cm}^{3}$ for birch, $1.72 \mathrm{~g} / \mathrm{cm}^{3}$ for pine, $1.61 \mathrm{~g} / \mathrm{cm}^{3}$ for spruce, and $1.55 \mathrm{~g} / \mathrm{cm}^{3}$ for linden.

For blueberry-type spruce forests on loamy soils, the porosity of soil aeration at depths of $5-30 \mathrm{~cm}$ on technological portages can be as low as $1-2 \%$ [86]. For comparative purposes, the average aeration porosity for loamy mineral soil is $25 \%$ [76]. When the aeration porosity decreases to $15 \%$, root growth decreases [34]. As a rule, tree roots need an oxygen concentration above $10 \%[52,76]$. Therefore, soil compaction can hinder natural tree renewal after logging. If a decrease in total porosity is accompanied by an increase in the volume humidity, moisture will accumulate over the entire profile of the affected soil. When the water content exceeds $75-80 \%$ of the total moisture capacity, waterlogging processes begin. Soil compaction can thus lead to reduced aeration and increased waterlogging, both of which are associated with unsatisfactory reforestation [86].

Compaction and rutting have also been reported to change the thermal regimes of soils after felling [4]. Changes in the temperature regime affect the dynamics of nutrients and organic matter and carbon dioxide emissions. Dymov and Startsev [22] note that soils are heated to greater depths after felling than they are in established young forests. As a result, the sum of temperatures for the two soil types differed by over $5{ }^{\circ} \mathrm{C}$ and the sum of active temperatures differed by more than $10^{\circ} \mathrm{C}$ over a six-year period.

Studies on wet and moist powdery loams after the passage of Ponsse ELK and John Deere 1410 machines in the Republic of Karelia and the Tver region of Russia show that strong compaction of the soil occurs during the first few machine passes. The authors note that the density of the surface layer $(0-5 \mathrm{~cm})$ of the soil increased in all studied cases even though the applied CTL (cut-to-length) systems comply with the environmental requirements concerning soil compaction for this type of soil $\left(1.4 \mathrm{~g} / \mathrm{cm}^{3}\right)[33,35]$.

A meta-analysis conducted by Mariotti et al. [66] confirmed that soil compaction during forest operations is a problem for forest regeneration.

Rut formation. Logging operations often cause compaction of the soil together with significant rutting. Pressure exerted through wheels and tracks often causes both vertical and horizontal displacement of the upper horizons, especially in soils with excessive or temporarily excessive moisture. The ruts are bounded by bulges, which tend to be more pronounced after wheeled vehicles than after tracked vehicles due to the smaller contact area $[45,64]$. Therefore, the use of tracked tractors in conditions of high humidity is preferable from the point of view of soil protection. However, some studies on soil compaction and rutting caused by tracked and wheeled vehicles have yielded contradictory results [15]. This may be due to differences in natural and technological conditions. The soil's susceptibility to rutting depends on the soil structure, the density of addition, and weather changes that affect the soil's moisture content [87]. Above the soil's critical moisture content, machine stress leads to rut formation.

The intensity of traffic (number of passes) is the main factor controlling rut depth $[24,25]$. In flat areas, ruts and other depressions are often sediment collectors and are filled with water for long periods, leading to gleying and local anaerobiosis [20]. This dramatically worsens the growing conditions of the forest's younger generation [32]. Our research shows that the amount of undergrowth in ruts is several times lower than in cutting strips [42].

On sites with even a slight slope, ruts direct surface runoff and are deepened by water erosion. The projected erosion rate depends mainly on the steepness and 
length of the slope and the inadequacy of coverage on the skid trails [31]. The risk of erosion increases with the degree of soil compaction because compaction increases the amount of water in the topmost soil horizon $(0-10 \mathrm{~cm})$ [62]. The environmental consequences of ruts can thus be significant, to the degree that the number and depth of ruts have been proposed as rough indicators of reduced productivity in an area [56] and of hydrological regime disruption.

The ruts formed by the passage of modern logging machines can be over $0.5 \mathrm{~m}$ deep [96]. Current sorting methods therefore do not satisfy the environmental requirements for thinning logging with respect to rut formation because the requirements state that track depths should be below $0.15 \mathrm{~m}$. The problem is especially severe on wet soils, where ruts can be up to $0.67 \mathrm{~m}$ deep $[33,35]$.

Studies by Ilintsev et al. [42] on rut formation showed that during summer harvesting on temporarily moist soils at sites with insufficient retention of logging residues, the depth of ruts reached 60-70 cm. Furthermore, a relationship was established between the quantity of logging residues and the rut depth. Observations at cuttings of different ages (from 1 to 15 years) showed that deep ruts smoothen out over time but do not completely disappear.

The formation of ruts during logging operations indicates that the weight of the loaded machinery exceeds the soil's load-bearing capacity. Therefore, further research is needed on the effects of using wheels and tracks and strengthening skid trails with logging residues to enable adaptation of logging methods to suit different environmental conditions.

Changes in chemical properties. Logging can disrupt the upper soil horizons, leading to increased mineralisation and leaching of some nutrients (phosphorus, potassium, etc.), usually lasting 2-5 years. Changes in the soil's nutrient regime may occur subsequently because this process is reversible and associated with changes in vegetation $[43,103]$.

The influence of logging machines on soil chemical properties is more pronounced in organogenic horizons than mineral ones [18], and changes have been observed up to $30-40 \mathrm{~cm}$ deep in the soil profile [29].

Logging changes both the composition of the soil organic matter and its distribution within the soil profile $[18,21,27,29,100]$. The role of the soil block (litter and humus) in the total reserves of organic carbon increases in fresh cuttings, where carbon replenishment over time is greatly reduced by a sharp reduction in litter fall onto the soil's surface [101]. For example, Fedchenko [27] and Varfolomeev [100] found that the content of organic carbon in the illuvial horizon in 1-11-year-old clearings was greater than in the soil of the stands untouched by logging. The authors attribute this change to accelerated litter decomposition and humification resulting from the cuttings' high humidity, which facilitates the movement of humus substances down the profile. The direction and intensity of the soil-forming process change significantly after final felling of spruce forests on drained podzolic soils with deep carbonates. This was related to the change in plant cover, the microbiological decomposition of acidic forest litter and logging residues, the formation of mobile acidic products such as fulvic acids during humification, and the increased movement of substances along the soil profile due to increased humidity.

McLaughlin and Phillips [67] found that the $\mathrm{C}$ and $\mathrm{N}$ contents of cuttings 17 years after logging are identical to those of unfelled stands. The organic matter content of forest soils is usually $1-5 \%$ of the dry mass and decreases with depth. Under natural 
conditions, the content of organic matter in soils is stable, but this may change when the balance of forest ecosystems is disturbed [76].

Changes in the qualitative composition of humus in cuttings were also highlighted in an analysis of soils at landing sites by Dymov and Lapteva [20], who observed a sharp increase in the proportion of humic acids (ha, represented mainly by the GF-1 fraction) in the humic substances (hs). This was reflected in an increase in the $\mathrm{C}_{\mathrm{ha}}: \mathrm{C}_{\mathrm{hs}}$ ratio in the upper half-metre of the profile to 1.0-2.1.

Dymov and Milanovskii [21] subsequently showed that this transformation of organic matter mainly involves the formation of hydrophilic components in the litter. Reactive hydrophilic humification products cause acid hydrolysis of minerals and accumulation of $\mathrm{Fe}-\mathrm{Al}$ organic compounds in the upper mineral horizons of the profile. In later stages, after 30-40 years, there is an increase in the density of the litter layer and a decrease in the acidity, thickness and mass fraction of organic carbon compared to the podzolic soils of the indigenous spruce stands.

Studies on the impact of various logging methods on the nitrogen content of sandy illuvial-ferruginous podzols formed on binomial sediments revealed that selective cutting changes the nature of the dynamics of mobile nitrogen in the soil and increases the intensity of formation of its mineral and labile organic forms [29]. During clear-cutting, the intensive formation of mineral forms of nitrogen leads to their loss from ecosystems due to their removal outside the soil profile. To prevent nitrogen depletion in soils after continuous logging, reforestation measures must be implemented within five years.

Högbom et al. [40] and Sah and Ilvesniemi [84] note that after clear logging in boreal forests, the abundance of $\mathrm{NH}_{4}{ }^{+}$containing the nitrogen isotope ${ }^{15} \mathrm{~N}$ increases in the upper organogenic horizon. This change is associated with increased nitrification. Additionally, the differences between the upper and lower horizons of the soil become smaller than in untouched plantings and the $\mathrm{NO}_{3}-\mathrm{N}$ content of the groundwater at a depth of $25 \mathrm{~cm}$ increase relative to controls.

In cutting areas in boreal forests, the content of mobile forms of phosphorus in the upper soil horizons decreases significantly but that of mobile potassium remains fairly stable [43]. Studies conducted in Iran [75] show that after summer skidding on the skid trails, there is a decrease in phosphorus and potassium that depends on the skidding tractor's number of passes and the slope of the terrain. The mobility of phosphorus is determined by the acidic reaction of the medium [57]. Similar results were obtained during winter logging in the forests of the Czech Republic [71].

As noted by Zetterberg et al. [105], the presence and abundance of various chemical elements in the soils of clear cuts where logging residues are left differ from those at sites where logging residues are collected. Removal of all logging residues after clear and selective felling can reduce the productivity and vitality of the remaining trees and lead to acidification of the soil and surface water $[1,86]$. This is due to the removal of nutrients and buffers in the tops of trees, branches and needles [44]. However, long-term studies over 10 years have shown that differences in soil acidity between different harvesting options may become unreliable, indicating that the differences are not constant [12]. During the process of soil recovery, its acidity decreases.

A meta-analysis conducted by Hume et al. [41], based on 808 observations from 49 studies showed that harvesting, on average, has little effect on $\mathrm{C}$ stocks. Harvesting initially reduced mineral $\mathrm{N}$ reserves in the soil, while $\mathrm{C}, \mathrm{N}$ and $\mathrm{P}$ concentrations on the forest floor decreased but those in the soil increased or remained at the 
same level. The concentrations of $\mathrm{C}, \mathrm{N}$, and $\mathrm{P}$ on the forest floor increased, depending on the intensity of harvesting and were more pronounced in coniferous stands than in broad-leaved and mixed forests. Over time, the concentration of $\mathrm{C}$ and $\mathrm{N}$ decreased. The dynamics of $\mathrm{P}$ recovery after wood harvesting remain unclear due to a lack of research. The authors highlight the important effects of the intensity of harvesting and the duration of the logging turnover on the long-term availability of nutrients in the soil. The lag in the recovery of phosphorus concentrations after logging may indicate the separation of the phosphorus cycle from the carbon and nitrogen cycle, which is an issue in need of further studies.

Changes in biological properties. Many researchers $[15,60]$ confirm significant changes in biological variables due to soil compaction, and that the response of soil micro, meso, and macroorganisms may be different.

Battigelli et al. [6] found that logging with heavy soil compaction also reduces the total soil mesofauna, up to $93 \%$ relative to unfelled forests. For example, there are decreases in the abundance and activity of earthworms and in the biodiversity and abundance of microarthropods $[8,9]$. Soil compaction significantly reduces microbial biomass and microbial activity [30] due to negative changes in total porosity, pore size and bond distribution [104].

The biological activity of soils is determined by their particle size distribution and soil bulk density of addition [86]. For example, the biological activity of the surface layer of sandy soil is very high and tends to increase with increasing compaction. In loamy soil, the opposite trend is observed with a decrease in activity with increasing soil density. A sharp deterioration in the microbiological activity of soils compacted during logging may indicate a deterioration in their forest-growing properties and a decrease in the assimilation of nutrients by plants and the rate of their involvement in the biological cycle.

Dymov and Startsev [22], note that in fresh cuttings, an increase in daily temperatures and waterlogging of the soil leads to a decrease in the number of ecological and trophic groups of microorganisms and the functional activity of the microbiota. Shifting light in the soil due to wood harvesting can lead to short-term growth in microarthropods' abundance. Ongoing changes caused by logging also reduce biologically determined processes in the soil, such as respiration [7, 65].

All these biological changes in the soils cause the recovery processes in the cutting areas.

Recovery of soil properties. Studies by various authors [15, 36, 71, 72, 82] show that the duration of the period after logging is of great importance for analysing soil cover recovery processes.

Recovery is evident for several decades after logging, and irreversible damage occurs in some cases [36,51]. It should be taken into account that the rate of recovery of different soil properties will be different $[10,15]$. Recovery depends on the degree of initial compaction, implying that the choice of logging machinery and technology used can control the recovery dynamics [78].

Furthermore, the level of recovery seems to depend on the thickness of the soil. For example, 3-4 years after compaction, Goutal et al. [36] found structural recovery in the upper soil layer $(0-10 \mathrm{~cm})$ on soils of light grain size composition and partial recovery in the next layer $(10-20 \mathrm{~cm})$ in more clay soil.

The results show that partial restoration of disturbed heavy clay soil occurred 24 and 30 years after logging, and the surface horizon of the soil within the track did 
not differ from the undisturbed control soil. However, the results show that even 30 years is not enough to restore the soil completely. In addition, if it takes more than 30 years to restore the compacted soil of the skid trails, the area covered with skid trails should be considered unproductive soil for tree renewal unless tillage is carried out [17].

Recent results by Mohieddinnea et al. [72] show a trend of recovery over time and the dynamics of recovery from the surface to deeper layers. The predicted duration of full recovery was about 54 and 70 years for Luvisol and Podzol, respectively. The authors also noted that sandy neutral soils could recover in less than 20 years, which is facilitated by the soil's biological activity.

Soil restoration is first enhanced by contrasting climatic conditions, such as moistening-drying and freezing-thawing [95]. Thus, the rate of restoration of the original properties varies from different factors. For example, the soil's original properties and the degree of exposure, which is observed in both Russian and foreign studies.

However, data on soil cover recovery processes after logging, especially over a long period, is currently insufficient. It is necessary to trace the course and period of recovery of both the properties and the structure of different soils in typological terms, which will allow us to talk about the prospects for the preservation and recovery of forest ecosystems.

\section{Methods of minimising damage and protecting forest soils}

Factors affecting the degree of damage to forest soils. Factors that affect the degree of damage to the soil's surface during logging operations can be divided into natural and technological factors (fig.). The level of disturbance is determined by natural factors including the soil type $[61,85]$, the terrain and direction of movement [47], soil moisture [38, 68], the organic matter content [15], soil texture, the proportion of skeleton and sand particles in the soil, soil bulk density and porosity, and the thickness of the humus accumulation layer [4], the slope, and the season [90].

The severity of the damage depends on technological factors that mostly relate to the forest machines; they include the driving force [15, 24], the mass of the vehicle, the load per axle/wheel/track contact area of the vehicle with the soil, the tire pressure $[13,15,45]$, the number of passes made by machines [38], the characteristics of the additional equipment, the organisation of the skidding process [64], speed, and wheel slip [24].

For example, the extent to which the forest floor and soil are disturbed depends on the skidding method, skidding machines, and soil conditions. On flat or slightly sloping terrain, wheeled vehicles are generally preferred due to their higher productivity $[15,91]$. Therefore, skidding operations should be rationally designed to account for factors that affect logging costs and productivity as well as the major factors affecting soil compaction [70].

The main methods of regulating and reducing damage to the soil cover during logging operations should include all forest management stages, from planning and the choice of technologies for use in the cutting area to the environmental training of personnel.

Accounting for natural factors when planning logging operations. Preliminary planning of logging operations in each cutting area is important. When assessing the potential impact of logging operations on the forest environment, it is necessary to consider all of the factors that may affect the degree of damage to the soil cover. 

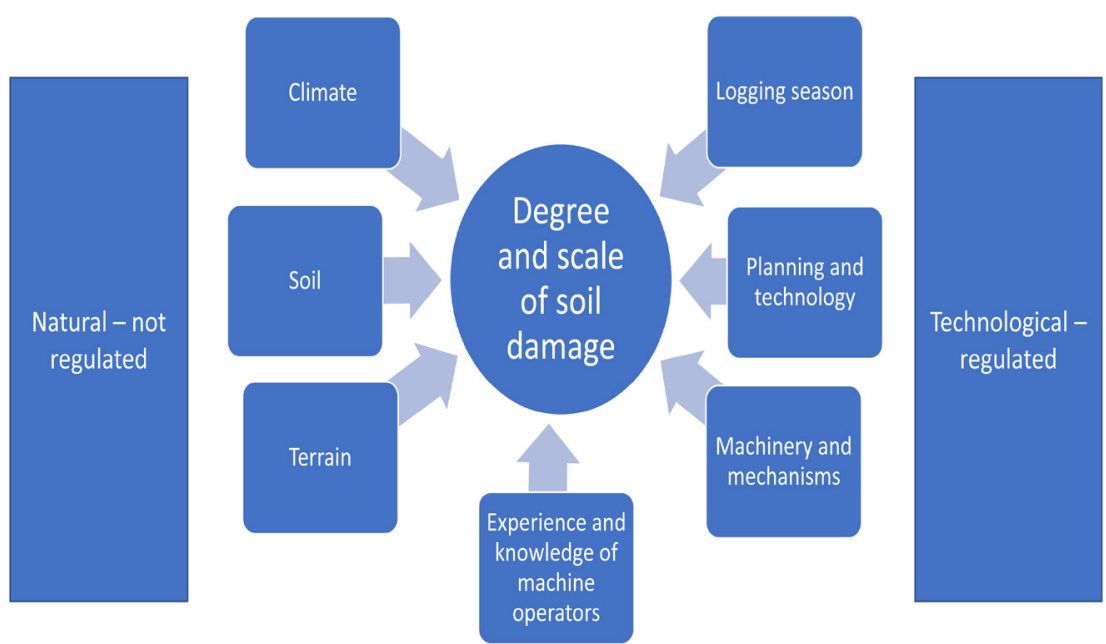

Factors controlling the degree and scale of impact on the soil during logging operations

Publicly available topographic and space maps, digital models of the terrain (surface) of high spatial resolution (https://www.pgc.umn.edu/data/arcticdem/), and forest management and field materials for determining terrain conditions should be used when drawing the harvest site planning map and planning the road and skid trail network.

Selection of the wood harvesting system. Three different wood harvesting systems may be used: full-tree (FT), tree-length (TL) and cut-to-length (CTL) [49]. Each system has its own characteristics that depend on the natural and production conditions, the technology used, and the share of manual operations in the overall process [34]. Globally, two systems are dominant - TL ('Canadian') and CTL ('Scandinavian'). All wood harvesting systems used in Russia have different negative effects on the forest environment [96]. All systems have almost identical effects on light soils, sandy soils, or sandy loam. However, sandy and sandy loam soils are much less common in Russian forests than medium and heavy soils (loam and clay). On such soils, FT and TL systems cause significant soil compaction but do not tend to form deep ruts. Katarov et al. [50] has argued that practices for implementing the CTL system on wet and moist soils should be modified to reduce rut depths in the most common forest soils.

Planning the logging season. The degree of damage to the soil depends on the season in which logging is done and the current weather conditions. The impact of logging machines will be lowest in winter [93], when the soil is frozen and its load-bearing capacity is therefore at a maximum. The depth of frozen soil primarily depends on the number of days with temperatures below $0{ }^{\circ} \mathrm{C}$, the thickness of the snow cover, the water content of the soil and the thickness of individual horizons [83]. Soil damage may occur in winter if only the upper soil horizons have only frozen or if the soil's temperature changes during the day, causing it to thaw.

The forest industry in Russia and the Nordic countries [87] has already faced problems due to abnormally warm winters without severe frosts [58]. Climate fluctuations resulting in land surface temperature anomalies are causing increasingly mild winters with unstable weather, leading to soil thawing and limited snow cover, both of which increase the risk of soil disturbance. Climate change and weather conditions should therefore be taken into account when organising wood harvesting: it is important 
to be aware of when the soil will be wet, dry, frozen, or covered with snow, and to adapt one's plans accordingly.

Planning the technology of logging operations. Optimal skidding (transportation) of wood with minimal impact on the soil cover requires proper planning of the density of the forest road network, including skid trails, strip roads, landing sites, and production and household sites. The technology used in logging operations depends on the size of the cutting areas, the wood harvesting system and the types of cutting to be performed. Three distinct classes of machines can be used in logging operations: narrow-, mediumand wide-range [96]. The area occupied by skid trails when using narrow-, medium, and wide-range machines is $15-25,10-15$, and 3-6 \% respectively.

Negative impacts on soil due to logging can be further limited by combining a mechanised CTL system with manual felling using chainsaws and manual transport (forwarder) loading, both of which reduce the number of skid trails in logging areas [15]. Such combined systems have no restrictions and can be implemented using medium-range (wide-range) logging technologies when performing selective logging such as thinning or gradual logging. Timber landing sites, production facilities, and machinery parking areas should be located on well-drained soil.

Planning of the trail network. There are standard schemes for placing skid trails on the cutting area that are used in diverse natural and climatic contexts. The criteria governing the layouts of skid trails are the terrain, soil conditions, wetlands, the presence of temporary and permanent watercourses, the position of the targeted stands within the cutting area, and the landing method. It is also necessary to consider forestry requirements and current regulatory rules, and to ensure that the average skidding distance of tracked tractors does not exceed $300 \mathrm{~m}$. When skidding with wheeled tractors the skidding distance can be increased up to $500 \mathrm{~m}$, or even to $1000 \mathrm{~m}$ in some cases [3]. The locations of landing sites, non-operational areas, key biotopes, and key stand elements in the cutting area should be taken into account in order to minimise the negative impact of logging.

Leaving logging residues on the soil's surface to strengthen the upper soil horizons. Numerous studies have show that reinforcing skid trails with logging residues (brash mats and corduroy bridges) significantly reduces changes in soil properties such as bulk density, porosity, and rutting when compared to unreinforced skid trails and also significantly increases the soil's load-bearing capacity [25].

Studies [54] showed that the peak load on the soil was reduced significantly by using more than $10 \mathrm{~kg}$ per $1 \mathrm{~m}^{2}$ of brush mats compared to when the brush mats were not used. It is recommended to leave at least $15-20 \mathrm{~kg} / \mathrm{m}^{-2}$ of brash mats on soils with low load-bearing capacities. While the brash mats lose some of their load-sharing capacity with each machine pass, they remain effective after up to 12 forwarder passes.

Ilintsev et al. [42] showed that cutting strips usually contain additional logging residues that could be laid on skid trails. The distribution and abundance of these residues may depend on the composition, stock, and density of the stand [55].

The properties of the coverage material also significantly affect soil compaction: branches and tops reduce compaction more effectively than chips and sawdust [2]. Other authors recommend covering skid trails with sawmills or pallets [77].

In the Nordic countries, there is considerable interest in using logging residues to produce bioenergy. If this waste is used to generate energy, it cannot be used to strengthen skid trails [24] because materials used for strengthening are often contaminated with soil and become unsuitable for further use. Wood used to construct 
wooden strip roads and temporary bridges or to strengthen skid roads is also unsuitable for the pulp and sawmilling industry [92]. Temporary bridges and strip roads made of pulpwood can be built to enable the movement of machines over crossings of temporary watercourses and on soils with low load-bearing capacities. For further reinforcement, residual wood can be placed on top of the temporary bridge.

Training of specialists working in the forest. Sirén et al. [87] note that effective use of the various thematic maps and additional planning tools that are available requires knowledge of the soil properties at the sites of interest and how they are affected by logging activities. The experience and knowledge of foresters and machine operators is thus important in the planning of logging operations. In particular, accurate knowledge of the location and volume of the various wood grades and the soil's load-bearing capacity is needed. Using this data can help forwarder operators to identify optimal driving tactics and minimise the number of passes through areas with low load-bearing capacities. Therefore, operators, foresters, and engineers should be offered additional training on the environmental aspects of forest management and ways of reducing negative impacts on the soil, stand, and undergrowth. Work programmes for training new specialists should also cover modern scientifically-based practical and technological solutions.

Selection of machine systems and mechanisms. A wide range of machines for forest management has been introduced in recent years. Therefore, the choice of machine systems is a key step when designing technological process for logging operations in specific natural and climatic conditions [81]. A machine system includes machines designed to perform specific sequences of technological operations such as felling, delimbing, bucking, skidding, sorting, and landing [28].

The different load-bearing capacities of different soils must be accounted for when selecting machine systems [77] (table 2).

Some machines are more suitable than others for specific soils with different load-bearing capacities. The period of wood harvesting must also be considered because large temporary fluctuations in the soil's bearing capacity can be expected, especially in sensitive areas. For example, peat soil can withstand a pressure of $80 \mathrm{kPa}$ in dry summers but only $20 \mathrm{kPa}$ in wet conditions. The nominal pressure exerted by a machine is highly dependent on its tire size and the overall vehicle configuration [77].

Reducing the number of vehicle passes over the skid trails. The number of vehicle passes significantly affects the degree and scale of soil damage. Most studies $[33,38,50]$ show that soil compaction is highest during the first few machine passes, and that the soil bulk density and depth of compaction increase more slowly with subsequent passes. Therefore, to reduce negative impacts on the soil, it is important to design and structure logging operations so as to optimise the passage and movement of machinery.

Use of larger tires. Increasing the tire width of an 8-wheeled 22-ton forwarder from 600 to $800 \mathrm{~mm}$ reduces its track depth by about $50 \%$ [15]. While increasing the wheel diameter and the tires' width effectively reduces the pressure on the soil, this approach has some limitations. For example, wide tires require a lot of space, which may be undesirable when thinning young trees [104]. 


\begin{tabular}{|c|c|c|c|c|c|}
\hline \multirow{9}{*}{ 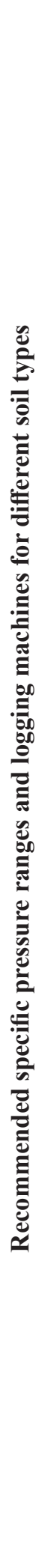 } & है & 1 & 1 & 1 & 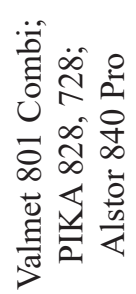 \\
\hline & $\begin{array}{l}\frac{\vec{v}}{\bar{v}} \\
\frac{\vec{v}}{\omega}\end{array}$ & I & I & 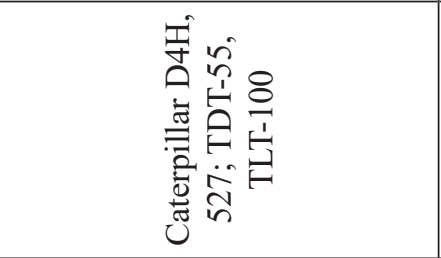 & 1 \\
\hline & 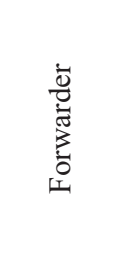 & 1 & 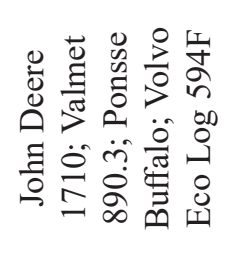 & 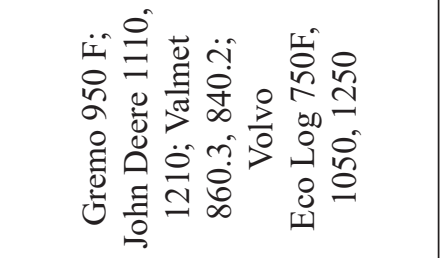 & 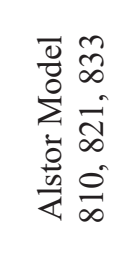 \\
\hline & 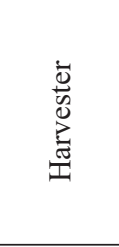 & 1 & 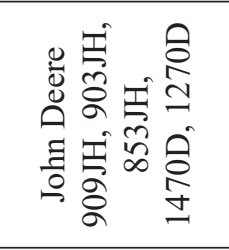 & 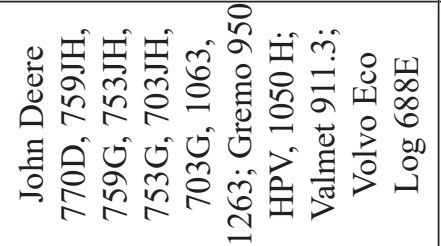 & 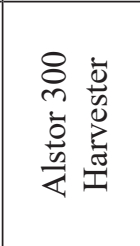 \\
\hline & 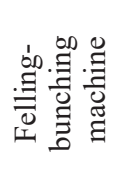 & I & 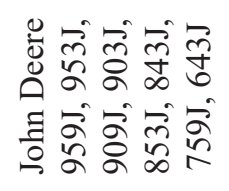 & 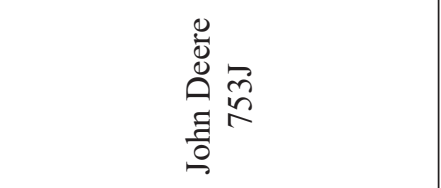 & 1 \\
\hline & 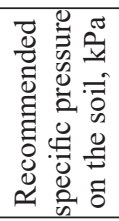 & $\stackrel{\infty}{\wedge}$ & $\begin{array}{l}\triangleright \\
1 \\
0\end{array}$ & $\begin{array}{l}8 \\
0 \\
8\end{array}$ & $\stackrel{\stackrel{P}{V}}{\text { P }}$ \\
\hline & 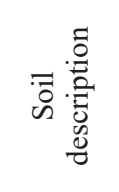 & 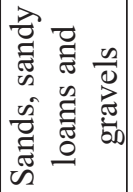 & 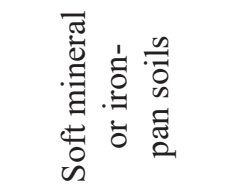 & 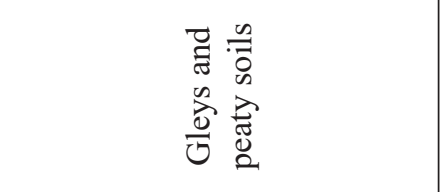 & $\begin{array}{c}\stackrel{\tilde{\Xi}}{\Xi} \\
\stackrel{2}{2}\end{array}$ \\
\hline & 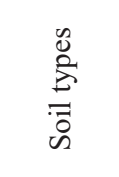 & $\vec{A}$ & 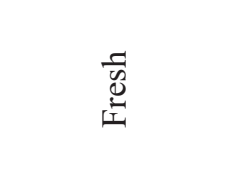 & 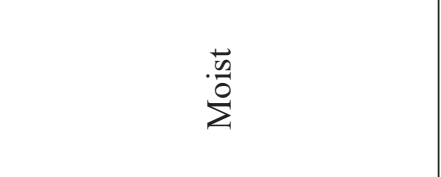 & 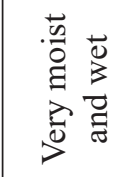 \\
\hline & 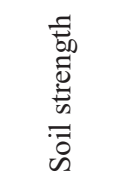 & 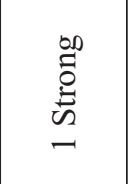 & 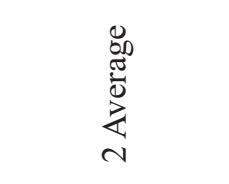 & $\begin{array}{l}\text { क्ष } \\
\text { in } \\
\text { m }\end{array}$ & 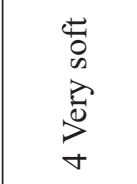 \\
\hline
\end{tabular}


Controlling the tire pressure. Manufacturers specify appropriate minimum, optimal, and maximum permissible internal air pressures for the different tires that they offer [81]. This enables the use of tire pressure control systems that allow the tire pressure to be adjusted to suit specific working conditions, which can improve traction and mobility and increase access during rainy seasons [15]. On secondary skid trails where there are fewer driveways than on main skid trails, the use of a forwarder with low-pressure tires can limit soil compaction to a degree [24]. To further reduce the risk of compaction, low-pressure tires are usually paired with anti-skid tracks, which are used for extended periods.

The use of snow chains. The use of chains on the front wheels reduces the load when the wheels slip, thereby reducing soil damage and increasing the vehicle's mobility [94].

The use of track belts. When organising the work of wheeled vehicles in heavy soil conditions, various measures can be taken to increase the cross-country ability of vehicles and reduce their negative impact on the soil. The most effective and common such measures are reducing the tires' internal pressure and installing removable tracks [81].

Fitting long rectangular tracks (track belts) significantly increases the machine's contact area with the soil, allowing its mass to be distributed over a larger support area. This reduces the pressure on the soil by a factor of 1.5 to 2 . Although track belts increase the weight on the trailer by $10-12 \%$, they can reduce the track depth (by 30-40\%) and the degree of soil compaction when compared even to fairly wide $(700 \mathrm{~mm})$ and soft tires [33]. This is probably due to reduction of the relative coefficient of rolling resistance [13].

Anti-skid tracks are also used to increase traction, load capacity, cross-country ability, speed, stability, and operator comfort, especially in hard-to-reach areas and on wet (moist) soils $[14,81]$. In a machine with a $6 \times 6$ wheel configuration, track belts will typically cover the wheels of the rear truck, whereas with an $8 \times 8$ configuration, track belts would be used on the front and rear pairs of wheels [74]. Using track setups adapted to specific wheel configurations and tire sizes allows machines to perform well and achieve high productivity under diverse natural and industrial conditions while also minimizing their environmental impact. For example, the use of track belts on the rear trolley of a 3-axle forwarder reduced its nominal pressure to $50-60 \mathrm{kPa}$, and using track belts on the front and rear bogies of a 4-axle forwarder reduced its nominal pressure to $40-50 \mathrm{kPa}$ [77].

It should be noted however that the use of wider tires and anti-skid tracks is not always sufficient to avoid damage to the soil surface; even if all of the currently available technical solutions are applied, it can be difficult to completely prevent soil damage. As pointed out by Cambi et al. [15], the technological equipment available today is simply not good enough.

Conducting melioration in wet areas. Melioration during site preparation can help remove excess moisture and thereby increase the soil's bearing capacity. For example, shallow-groove melioration reduces high local groundwater levels and improves aeration of the upper soil horizons [59]. The main limitations of mechanical site preparation methods are the high cost of work and the potential consequences of repeated machine movements.

Use of global positioning systems (GPS) and geographic information systems (GIS). Logging management involves equipping modern logging machinery with 
navigation components (GPS) and GIS to provide accurate information on the vehicle's location in relation to bodies of water, swampy areas, and so on. Detailed operational planning using technologies such as real-time mapping can help technicians avoid wet and lowered areas and thereby reduce potential soil damage.

\section{Conclusion}

This paper has summarised the results of studies on how different types of mechanised logging can affect the forest environment and soil to varying degrees by changing the soil's physical, chemical, and biological properties and by causing mechanical damage (rutting). The process of soil rehabilitation after logging operations may take many decades, and some damage is irreparable. Therefore, given the strong influence of soils on forest productivity, it is essential to conserve and protect forest soils in order to ensure the successful renewal and productivity of future forests. The soil must be maintained in a healthy state to ensure environmental stability and the preservation of forest flora and fauna.

Despite the high interest in sparing methods of wood harvesting, current measures for preserving forest soils after logging operations are insufficient. Based on this review of field management practices for reducing adverse impacts on soils and soil cover, it can be concluded that there are effective ways to reduce the negative impact of logging activities. While there are no regulatory requirements to reduce negative impacts on soils during logging, voluntary forest certification could potentially serve a similar purpose. Efforts to reduce soil damage are also hindered by the limitations of the current scientific and technical knowledge base and the high cost of implementing best management practices. Furthermore, economic factors including production plans, the growing demand for forest products, the cost of harvesting wood, and the need to pay taxes and rent, all require the continuous harvesting of wood throughout the year even when weather conditions are unfavourable.

Therefore, major goals for future research in this area should be to clarify the impact of logging machinery and equipment on soils, identify optimal processes and measures for promoting the rehabilitation of soil cover and the best times for implementing such processes and measures, and develop guidelines, regulatory documents and accessible large-scale soil maps to support scientifically sound forest management that takes climate change into account and aims to reduce the negative impact of logging machinery on soil cover.

\section{REFERENCES}

1. Achat D.L., Deleuze C., Landmann G., Pousse N., Ranger J., Augusto L. Quantifying Consequences of Removing Harvesting Residues on Forest Soils and Tree Growth A Meta-Analysis. Forest Ecology and Management, 2015, vol. 348, pp. 124-141. DOI: https://doi.org/10.1016/j.foreco.2015.03.042

2. Akay A.E., Yuksel A., Reis M., Tutus A. The Impacts of Ground-Based Logging Equipment on Forest Soil. Polish Journal of Environmental Studies, 2007, vol. 16, no. 3, pp. 371-376.

3. Ananiev V.A., Asikainen A., Vialkko E., Gerasimov Y.Y., Dyomin K.K., Sikanen L., Sunyov V.S., Tyukina O.N., Khlustov V.K., Shirnin Y.A. Intermediate Yield of Forest in the North-West of Russia. Joensuu, Research Institute of the Forest of Finland, 2005. 150 p. 
4. Arnup R.W. The Extent, Effect and Management of Forestry-Related Soil Disturbance, with Reference to Implications for the Clay Belt: A Literature Review. Technical Report TR-37. Ontario, Northeast Science and Technology, 1998. 30 p.

5. Bagheri I., Kalhori S.B., Akef M., Khormali F. Effect of Compaction on Physical and Micromorphological Properties of Forest Soils. American Journal of Plant Sciences, 2012, vol. 3, no. 1, pp. 159-163. DOI: https://doi.org/10.4236/ajps.2012.31018

6. Battigelli J.P., Spence J.R., Langor D.W., Berch S.M. Short-Term Impact of Forest Soil Compaction and Organic Matter Removal on Soil Mesofauna Density and Oribatid Mite Diversity. Canadian Journal of Forest Research, 2004, vol. 34, no. 5, pp. 1136-1149. DOI: https://doi.org/10.1139/x03-267

7. Beylich A., Oberholzer H.-R., Schrader S., Höper H., Wilke B.-M. Evaluation of Soil Compaction Effects on Soil Biota and Soil Biological Processes in Soils. Soil and Tillage Research, 2010, vol. 109, iss. 2, pp. 133-143. DOI: https://doi.org/10.1016/j.still.2010.05.010

8. Blasi S., Menta C., Balducci L., Conti F.D., Petrini E., Piovesan G. Soil Microarthropod Communities from Mediterranean Forest Ecosystems in Central Italy under Different Disturbances. Environmental Monitoring and Assessment, 2013, vol. 185, pp. 1637-1655. DOI: https://doi.org/10.1007/s10661-012-2657-2

9. Bottinelli N., Capowiez Y., Ranger J. Slow Recovery of Earthworm Populations after Heavy Traffic in Two Forest Soils in Northern France. Applied Soil Ecology, 2014, vol. 73, pp. 130-133. DOI: https://doi.org/10.1016/j.apsoil.2013.08.017

10. Bowd E.J., Banks S.C., Strong C.L., Lindenmayer D.B. Long-Term Impacts of Wildfire and Logging on Forest Soils. Nature Geoscience, 2019, vol. 12, pp. 113-118. DOI: https://doi.org/10.1038/s41561-018-0294-2

11. Brais S. Persistence of Soil Compaction and Effects on Seedling Growth in NorthWestern Quebec. Soil Science Society of America Journal, 2001, vol. 65, iss. 4, pp. 1263-1271. DOI: https://doi.org/10.2136/sssaj2001.6541263x

12. Brandtberg P.-O., Olsson B.A. Changes in the Effects of Whole-Tree Harvesting on Soil Chemistry during 10 Years of Stand Development. Forest Ecology and Management, 2012, vol. 277, pp. 150-162. DOI: https://doi.org/10.1016/j.foreco.2012.04.019

13. Bygdén G., Eliasson L., Wästerlund I. Rut Depth, Soil Compaction and Rolling Resistance when Using Bogie Tracks. Journal of Terramechanics, 2003, vol. 40, iss. 3, pp. 179-190. DOI: https://doi.org/10.1016/j.jterra.2003.12.001

14. Bygdén G., Wästerlund I. Rutting and Soil Disturbance Minimized by Planning and Using Bogie Tracks. Forestry Studies, 2007, vol. 46, pp. 5-12.

15. Cambi M., Certini G., Neri F., Marchi E. Impact of Heavy Traffic on Forest Soils: A Review. Forest Ecology and Management, 2015, vol. 338, pp. 124-138. DOI: https://doi.org/10.1016/j.foreco.2014.11.022

16. Cambi M., Hoshika Y., Mariotti B., Paoletti E., Picchio R., Venanzi R., Marchi E. Compaction by a Forest Machine Affects Soil Quality and Quercus robur L. Seedling Performance in an Experimental Field. Forest Ecology and Management, 2017, vol. 384, pp. 406-414. DOI: https://doi.org/10.1016/j.foreco.2016.10.045

17. DeArmond D., Emmert F., Lima A.J.N., Higuchia N. Impacts of Soil Compaction Persist 30 Years after Logging Operations in the Amazon Basin. Soil and Tillage Research, 2019, vol. 189, pp. 207-216. DOI: https://doi.org/10.1016/j.still.2019.01.010

18. Dolgaya V.A., Bakhmet O.N. Forest Litter Layer Properties on the Early Stages of Natural Regrowth after Clear Cuts in Karelian Middle Taiga. Lesovedenie [Russian Journal of Forest Science], 2021, no. 1, pp. 65-77. DOI: https://doi.org/10.31857/S0024114821010022 
19. Dymov A.A. The Impact of Clearcutting in Boreal Forests of Russia on Soils: A Review. Eurasian Soil Science, 2017, vol. 50, iss. 7, pp. 780-790. DOI: https://doi.org/10.1134/ $\underline{\mathrm{S} 106422931707002 \mathrm{X}}$

20. Dymov A.A., Lapteva E.M. Changes in Podzolic Soils on Bilayered Deposits under the Influence of Felling. Lesovedenie [Russian Journal of Forest Science], 2006, no. 3, pp. 42-49.

21. Dymov A.A., Milanovskii E.Y. Changes in the Organic Matter of Taiga Soils during the Natural Reafforestation after Cutting in the Middle Taiga of the Komi Republic. Eurasian Soil Science, 2014, vol. 46, no. 12, pp. 1164-1171. DOI: https://doi.org/10.1134/ $\underline{\mathrm{S} 1064229314010049}$

22. Dymov A.A., Startsev V.V. Changes in the Temperature Regime of Podzolic Soils in the Course of Natural Forest Restoration after Clearcutting. Eurasian Soil Science, 2016, vol. 49, no. 5, pp. 551-559. DOI: https://doi.org/10.1134/S1064229316050021

23. Edlund J., Bergsten U., Löfgren B. Effects of Two Different Forwarder Steering and Transmission Drive Systems on Rut Dimensions. Journal of Terramechanics, 2012, vol. 49, iss. 5, pp. 291-297. DOI: https://doi.org/10.1016/j.jterra.2012.03.004

24. Eliasson L. Effects of Forwarder Tyre Pressure on Rut Formation and Soil Compaction. Silva Fennica, 2005, vol. 39, no. 4, pp. 549-557. DOI: https://doi.org/10.14214/sf.366

25. Eliasson L., Wästerlund I. Effects of Slash Reinforcement of Strip Roads on Rutting and Soil Compaction on a Moist Fine-Grained Soil. Forest Ecology and Management, 2007, vol. 252, iss. 1-3, pp. 118-123. DOI: https://doi.org/10.1016/j.foreco.2007.06.037

26. Enström J. Grundbok för skogsbrukare. Jönköping, Skogsstyrelsen, 1996. 189 p.

27. Fedchenko M.A. On the Group Composition of Soil Humus of Deschampsia Clear-Cuts of the Arkhangelsk Region. Pochvovedenie [Eurasian Soil Science], 1962, no. 1, pp. 49-58.

28. Fedorenchik A.S., German A.A., Protas P.A. Forest Machines “Amkodor”. Minsk, BGTU Publ., 2013. 240 p.

29. Fedorets N.G., Bahmet O.N. Ecological Settings of Carbohydrate and Nitrogen Transformations in Forest Soils. Petrozavodsk, KRC RAS Publ., 2003. 240 p.

30. Frey B., Kremer J., Rüdt A., Sciacca S., Matthies D., Lüscher P. Compaction of Forest Soils with Heavy Logging Machinery Affects Soil Bacterial Community Structure. European Journal of Soil Biology, 2009, vol. 45, iss. 4, pp. 312-320. DOI: https://doi.org/10.1016/j.ejsobi.2009.05.006

31. Garren A.M., Bolding M.C., Aust W.M., Moura A.C., Barrett S.M. Soil Disturbance Effects from Tethered Forwarding on Steep Slopes in Brazilian Eucalyptus Plantations. Forests, 2019, vol. 10, iss. 9, art. 721. DOI: https://doi.org/10.3390/f10090721

32. Gebauer R., Neruda J., Ulrich R., Martinková M. Soil Compaction - Impact of Harvesters' and Forwarders' Passages on Plant Growth. Sustainable Forest Management - Current Research. Ed. by J.J. Diez. InTech, 2012, pp. 180-196. DOI: https://doi.org/10.5772/30962

33. Gerasimov Yu., Katarov V. Effect of Bogie Track and Slash Reinforcement on Sinkage and Soil Compaction in Soft Terrains. Croatian Journal of Forest Engineering, 2010, vol. 31, no. 1, pp. 35-45.

34. Gerasimov Yu., Sokolov A. Ergonomic Evaluation and Comparison of Wood Harvesting Systems in Northwest Russia. Applied Ergonomics, 2014, vol. 45, iss. 2, part B, pp. 318-338. DOI: https://doi.org/10.1016/j.apergo.2013.04.018

35. Goltsev V., Tolonen T., Syunev V., Dahlin B., Gerasimov Y. Wood Harvesting and Logistics in Russia - Focus on Research and Business Opportunities. Final Report of the Research Project. Working Papers of the Finnish Forest Research Institute 210. Joensuu, 
MELTA, 2011. 157 p. Available at: http://www.metla.fi/julkaisut/workingpapers/2011/ mwp210.pdf (accessed 01.03.20).

36. Goutal N., Boivin P., Ranger J. Assessment of the Natural Recovery Rate of Soil Specific Volume Following Forest Soil Compaction. Soil Science Society of America Journal, 2012, vol. 76, iss. 4, pp. 1426-1435. DOI: https://doi.org/10.2136/sssaj2011.0402

37. Gusev I.I., Kozobrodov A.S., Kubrak N.I., Nevolin O.A., Pleshak T.V., Tret'yakov S.V. The Current State of Forest Resources of the Arkhangelsk Region and the Environmental Consequences of Forest Management. Environmental Problems of the European North: Collection of Academic Papers. Yekaterinburg, 1996, no. 3, pp. 9-24.

38. Han H.-S., Page-Dumroese D.S., Han S.-K., Tirocke J. Effect of Slash, Machine Passes, and Soil Moisture on Penetration Resistance in a Cut-to-Length Harvesting. International Journal of Forest Engineering, 2006, vol. 17, iss. 2, pp. 11-24. DOI: https://doi.org/10 $.1080 / 14942119.2006 .10702532$

39. Hattori D., Tanaka K., Irino K.O., Kendawang J.J., Ninomiya I., Sakurai K. Effects of Soil Compaction on the Growth and Mortality of Planted Dipterocarp Seedlings in a Logged-Over Tropical Rainforest in Sarawak Malaysia. Forest Ecology and Management, 2013, vol. 310, pp. 770-776. DOI: https://doi.org/10.1016/j.foreco.2013.09.023

40. Högbom L., Nilsson U., Örlander G. Nitrate Dynamics after Clear Felling Monitored by in vivo Nitrate Reductase Activity (NRA) and Natural 15N Abundance of Deschampsia flexuosa (L.) Trin. Forest Ecology and Management, 2002, vol. 160, iss. 1-3, pp. 273-280. DOI: https://doi.org/10.1016/s0378-1127(01)00475-3

41. Hume A.M., Chen H.Y.H., Taylor A.R. Intensive Forest Harvesting Increases Susceptibility of Northern Forest Soils to Carbon, Nitrogen and Phosphorus Loss. Journal of Applied Ecology, 2017, vol. 55, iss. 1, pp. 246-255. DOI: https://doi.org/10.1111/1365$\underline{2664.12942}$

42. Ilintsev A., Bogdanov A., Nakvasina E., Amosova I., Koptev S., Tretyakov S. The Natural Recovery of Disturbed Soil, Plant Cover and Trees after Clear-Cutting in the Boreal Forests, Russia. iForest - Biogeosciences and Forestry, 2020, vol. 13, iss. 6, pp. 531-540. DOI: https://doi.org/10.3832/ifor3371-013

43. Ilintsev A., Nakvasina E., Aleynikov A., Tretyakov S., Koptev S., Bogdanov A. Middle-Term Changes in Topsoils Properties on Skidding Trails and Cutting Strips after Long-Gradual Cutting: A Case Study in the Boreal Forest of the North-East of Russia. Croatian Journal of Forest Engineering, 2018, vol. 39, no. 1, pp. 71-83.

44. Iwald J., Löfgren S., Stendahl J., Karltun E. Acidifying Effect of Removal of Tree Stumps and Logging Residues as Compared to Atmospheric Deposition. Forest Ecology and Management, 2013, vol. 290, pp. 49-58. DOI: https://doi.org/10.1016/j.foreco.2012.06.022

45. Jansson K.-L., Johansson J. Soil Changes after Traffic with a Tracked and a Wheeled Forest Machine: A Case Study on a Silt Loam in Sweden. Forestry, 1998, vol. 71, iss. 1, pp. 57-66. DOI: https://doi.org/10.1093/forestry/71.1.57

46. Jansson K.-J., Wästerlund I. Effect of Traffic by Lightweight Forest Machinery on the Growth of Young Picea abies Trees. Scandinavian Journal of Forest Research. 1999, vol. 14, iss. 6, pp. 581-588. DOI: https://doi.org/10.1080/02827589908540823

47. Jourgholami M., Majnounain B., Abari M.E. Effects of Tree-Length Timber Skidding on Soil Compaction in the Skid Trail in Hyrcanian Forests. Forest Systems, 2014, vol. 23, no. 2, pp. 288-293. DOI: https://doi.org/10.5424/fs/2014232-03766

48. Karpechko A.Yu. Changes in Density and Root Mass in Soils under the Influence of Harvesting Machines in Spruce Forests of Southern Karelia. Lesovedenie [Russian Journal of Forest Science], 2008, no. 5, pp. 66-70. 
49. Karvinen S., Välkky E., Torniainen T., Gerasimov Y. Northwest Russian Forestry in a Nutshell. Working Papers of the Finnish Forest Research Institute 30. Joensuu, MELTA, 2006. 98 p. Available at: http://www.metla.fi/julkaisut/workingpapers/2006/mwp030.pdf (accessed 01.03.20).

50. Katarov V.K., Syunev V.S., Ratjkova E.I., Gerasimov Y.Y. Impact of Wood Forwarding on Forest Soils. Resources and Technology, 2013, no. 9(2), pp. 73-81. DOI: http://dx.doi.org/10.15393/j2.art.2012.1641

51. Klaes B., Struck J., Schneider R., Schüler G. Middle-Term Effects after Timber Harvesting with Heavy Machinery on a Fine-Textured Forest Soil. European Journal of Forest Research, 2016, vol. 135, pp. 1083-1095. DOI: https://doi.org/10.1007/s10342-016-0995-2

52. Kozlowski T.T. Soil Compaction and Growth of Woody Plants. Scandinavian Journal of Forest Research, 1999, vol. 14, iss. 6, pp. 596-619. DOI: https://doi. org/10.1080/02827589908540825

53. Kuznetsova I.A., Danilova V.I. On Soil Decompression under the Influence of Swelling-Shrinkage Processes. Pochvovedenie [Eurasian Soil Science], 1988, no. 6, pp. 59-70.

54. Labelle E.R., Jaeger D. Quantifying the Use of Brush Mats in Reducing Forwarder Peak Loads and Surface Contact Pressure. Croatian Journal of Forest Engineering, 2012, vol. 33, no. 2, pp. 249-274.

55. Labelle E.R., Jaeger D. Management Implications of Using Brush Mats for Soil Protection on Machine Operating Trails during Mechanized Cut-to-Length Forest Operations. Forests, 2019, vol. 10, iss. 1, art. 19. DOI: https://doi.org/10.3390/f10010019

56. Lacey S.T., Ryan P.J. Cumulative Management Impacts on Soil Physical Properties and Early Growth of Pinus radiata. Forest Ecology and Management, 2000, vol. 138, iss. 1-3, pp. 321-333. DOI: https://doi.org/10.1016/S0378-1127(00)00422-9

57. Lambers H., Finnegan P.M., Laliberté E., Pearse S.J., Ryan M.H., Shane M.W., Veneklaas E.J. Phosphorus Nutrition of Proteaceae in Severely Phosphorus-Impoverished Soils: Are There Lessons to Be Learned for Future Crops? Plant Physiology, 2011, vol. 156, iss. 3, pp. 1058-1066. DOI: https://doi.org/10.1104/pp.111.174318

58. Land Surface Temperature Anomaly. December 2019. Available at: https://neo.sci. gsfc.nasa.gov/view.php?datasetId=MOD_LSTAD_M\&year=2019 (accessed 01.02.20).

59. Lang A.J., Cristan R., Aust W.M., Bolding M.C., Strahm B.D., Vance E.D., Roberts Jr. E.T. Long-Term Effects of Wet and Dry Site Harvesting on Soil Physical Properties Mitigated by Mechanical Site Preparation in Coastal Plain Loblolly Pine (Pinus taeda) Plantations. Forest Ecology and Management, 2016, vol. 359, pp. 162-173. DOI: https://doi.org/10.1016/j.foreco.2015.09.034

60. Li Q., Allen H.L., Wollum II A.G. Microbial Biomass and Bacterial Functional Diversity in Forest Soils: Effects of Organic Matter Removal, Compaction, and Vegetation Control. Soil Biology and Biochemistry, 2004, vol. 36, iss. 4, pp. 571-579. DOI: https://doi.org/10.1016/j.soilbio.2003.12.001

61. Magagnotti N., Spinelli R., Güldner O., Erler J. Site Impact after Motor-Manual and Mechanised Thinning in Mediterranean Pine Plantations. Biosystems Engineering, 2012, vol. 113, iss. 2, pp. 140-147. DOI: https://doi.org/10.1016/j.biosystemseng.2012.07.001

62. Magnusson T. Tjälskjutning. Skogsskötselserien nr13, Skogsbruk-mark och vatten. Skogsstyrelsen, 2009, p. 11.

63. Marchi E., Chung W., Visser R., Abbas D., Nordfjell T., Mederski P.S., McEwan A., Brink M., Laschi A. Sustainable Forest Operations (SFO): A New Paradigm in a Changing World and Climate. Science of the Total Environment, 2018, vol. 634, pp. 1385-1397. DOI: https://doi.org/10.1016/j.scitotenv.2018.04.084 
64. Marchi E., Picchio R., Spinelli R., Verani S., Venanzi R., Certini G. Environmental Impact Assessment of Different Logging Methods in Pine Forests Thinning. Ecological Engineering, 2014, vol. 70, pp. 429-436. DOI: https://doi.org/10.1016/j.ecoleng.2014.06.019

65. Mariani L., Chang S.X., Kabzems R. Effects of Tree Harvesting, Forest Floor Removal, and Compaction on Soil Microbial Biomass, Microbial Respiration, and N Availability in a Boreal Aspen Forest in British Columbia. Soil Biology and Biochemistry, 2006, vol. 38, iss. 7, pp. 1734-1744. DOI: https://doi.org/10.1016/j.soilbio.2005.11.029

66. Mariotti B., Hoshika Y., Cambi M., Marra E., Feng Z., Paoletti E., Marchi E. Vehicle-Induced Compaction of Forest Soil Affects Plant Morphological and Physiological Attributes: A Meta-Analysis. Forest Ecology and Management, 2020, vol. 462, art. 118004. DOI: https://doi.org/10.1016/j.foreco.2020.118004

67. McLaughlin J.W., Phillips S.A. Soil Carbon, Nitrogen, and base Cation Cycling 17 Years after Whole-Tree Harvesting in a Low-Elevation Red Spruce (Picea rubens)Balsam Fir (Abies balsamea) Forested Watershed in Central Maine, USA. Forest Ecology and Management, 2006, vol. 222, iss. 1-3, pp. 234-253. DOI: https://doi.org/10.1016/j.foreco.2005.10.033

68. McNabb D., Startsev A., Nguyen H. Soil Wetness and Traffic Level Effects on Bulk Density and Air-Filled Porosity of Compacted Boreal Forest Soils. Soil Science Society of America Journal, 2001, vol. 65, iss. 4, pp. 1238-1247. DOI: https://doi.org/10.2136/ sssaj2001.6541238x

69. Melekhov I.S. Forestry. Moscow, MSFU Publ., 2003. 320 p.

70. Melemez K., Tunay M., Emir T. A Comparison of Productivity in Five Small-Scale Harvesting Systems. Small-scale Forestry, 2014, vol. 13, pp. 35-45. DOI: https://doi.org/10.1007/s11842-013-9239-1

71. Modrý M., Hubený D. Impact of Skidder and High-Lead System Logging on Forest Soils and Advanced Regeneration. Journal of Forest Science, 2003, vol. 49, no. 6, pp. 273-280. DOI: https://doi.org/10.17221/4701-JFS

72. Mohieddinnea H., Brasseur B., Spicher F., Gallet-Moron E., Buridant J., Kobaissi A., Horen H. Physical Recovery of Forest Soil after Compaction by Heavy Machines, Revealed by Penetration Resistance over Multiple Decades. Forest Ecology and Management, 2019, vol. 449, art. 117472. DOI: https://doi.org/10.1016/j.foreco.2019.117472

73. Mokhirev A., Sul'tson S., Ivshina A. Adaptation of Wood Harvesting Technologies at the Enterprises of Krasnoyarsk Territory under the Principles of Voluntary Forest Certification. Lesotekhnicheskiy zhurnal [Forestry Engineering Journal], 2018, vol. 8, no. 4, pp. 163-178. DOI: https://doi.org/10.12737/article 5c1a3221bdddf8.81807282

74. Mokhirev A.P. The Method of Selection of Forest Machines under the Climatic Conditions. Lesotekhnicheskiy zhurnal [Forestry Engineering Journal], 2016, vol. 6, no. 4, pp. 208-215. DOI: https://doi.org/10.12737/23459

75. Naghdi R., Solgi A., Labelle E.R., Zenner E.K. Influence of Ground-Based Skidding on Physical and Chemical Properties of Forest Soils and Their Effects on Maple Seedling Growth. European Journal of Forest Research, 2016, vol. 135, pp. 949-962. DOI: https://doi.org/10.1007/s10342-016-0986-3

76. Osman K.T. Forest Soils: Properties and Management. Cham, Switzerland Springer, 2013. 217 p. DOI: https://doi.org/10.1007/978-3-319-02541-4

77. Owende P.M.O., Lyons J., Haarlaa R., Peltola A., Spinelli R., Molano J., Ward S.M. Operations Protocol for Eco-Efficient Wood Harvesting on Sensitive Sites. Project ECOWOOD, 2002. 74 p.

78. Picchio R., Mercurio R., Venanzi R., Gratani L., Giallonardo T., Monaco A.L., Frattaroli A.R. Strip Clear-Cutting Application and Logging Typologies for Renaturalization 
of Pine Afforestation - A Case Study. Forests, 2018, vol. 9, iss. 6, art. 366. DOI: https://doi. org/10.3390/f9060366

79. Pobedinskiy A.V. Water and Soil Protection Role of Forests. Pushkino, VNIILM Publ., 2013. 208 p.

80. Powers R.F., Scott D.A., Sanchez F.G, Voldseth R.A., Page-Dumroese D., Elioff J.D., Stone D.M. The North American Long-Term Soil Productivity Experiment: Findings from the First Decade of Research. Forest Ecology and Management, 2005, vol. 220, iss. 1-3, pp. 31-50. DOI: https://doi.org/10.1016/j.foreco.2005.08.003

81. Protas P.A., Misuno Yu.I. Investigation of the Pressure of the Forwarder "Amkodor 2661-01" Wheeler on the Base Surface. Trudy BGTU [Proceedings of BSTU], 2017, no. 2(198), pp. 251-258.

82. Rozhkov V.A., Karpachevskii L.O. The Forest Cover of Russia and Soil Conservation. Eurasian Soil Science, 2006, vol. 39, iss. 10, pp. 1041-1048. DOI: https://doi.org/10.1134/S1064229306100012

83. Saarilahti M. Soil Interaction Model. Appendix Report No 8. Helsinki, University of Helsinki, 2002. 37 p.

84. Sah S.P., Ilvesniemi H. Interspecific Variation and Impact of ClearCutting on Natural ${ }^{15} \mathrm{~N}$ Abundance and N Concentration in the Needle-to-Soil Continuum of a Boreal Conifer Forest. Plant Soil and Environment, 2007, vol. 53, iss. 8, pp. 329-339. DOI: https://doi.org/10.17221/2186-PSE

85. Sakai H., Nordfjell T., Suadicani K., Talbot B., Bøllehuus E. Soil Compaction on Forest Soils from Different Kinds of Tires and Tracks and Possibility of Accurate Estimate. Croatian Journal of Forest Engineering, 2008, vol. 29, iss.1, pp. 15-27.

86. Seryy V.S., Anikeyeva V.A., Vyalykh N.I., Kubrak N.I. Changing Forest Site Conditions of Cuttings in Modern Logging. Environmental Studies in the Forests of the European North: Collection of Academic Papers. Arkhangelsk, AILiLKh Publ., 1991, pp. 3-15.

87. Sirén M., Ala-Ilomäki J., Lindeman H., Uusitalo J., Kiilo K.E.K., Salmivaara A., Ryynänen A. Soil Disturbance by Cut-to-Length Machinery on Mid-Grained Soils. Silva Fennica, 2019, vol. 53, no. 2, art. 10134. DOI: https://doi.org/10.14214/sf.10134

88. Sokolovskaya N.A., Revut K.B., Markova I.A, Shevlyakov I.R. The Role of Soil Density in Reforestation. Lesovedenie [Russian Journal of Forest Science], 1977, no. 2, pp. 44-55.

89. Solgi A., Naghdi R., Marchi E., Laschi A., Behjou F.K., Hemmati V., Masumian A. Impact Assessment of Skidding Extraction: Effects on Physical and Chemical Properties of Forest Soils and on Maple Seedling Growing along the Skid Trail. Forests, 2019, vol. 10, iss. 2, art. 134. DOI: https://doi.org/10.3390/f10020134

90. Solgi A., Najafi A. The Impacts of Ground-Based Logging Equipment on Forest Soil. Journal of Forest Science, 2014, vol. 6, iss. 1, pp. 28-34. DOI: https://doi.org/10.17221/76/2013-JFS

91. Spinelli R., Magagnotti N. Wood Extraction with Farm Tractor and Sulky: Estimating Productivity, Cost and Energy Consumption. Small-scale Forestry, 2012, vol. 11, pp. 73-85. DOI: https://doi.org/10.1007/s11842-011-9169-8

92. Staland F., Larsson K. Bra planering och rätt teknik minskar risken för markskador. Skogforsk Resultat (4). Uppsala, Skogforsk, 2002. 4 p.

93. Šušnjar M., Horvat D., Šešelj J. Soil Compaction in Timber Skidding in Winter Conditions. Croatian Journal of Forest Engineering, 2006, vol. 27, no. 1, pp. 3-15.

94. Suvinen A. Economic Comparison of the Use of Tyres, Wheel Chains and Bogie Tracks for Timber Extraction. Croatian Journal of Forest Engineering, 2006, vol. 27, no. 2, pp. 81-102. 
95. Sveistrup T.E., Haraldsen T.K., Langohr R., Marcelino V., Kværner J. Impact of Land Use and Seasonal Freezing on Morphological and Physical Properties of Silty Norwegian Soils. Soil and Tillage Research, 2005, vol. 81, iss. 1, pp. 39-56. DOI: https://doi.org/10.1016/j.still.2004.05.004

96. Syunev V.S., Sokolov A.P., Konovalov A.P., Katarov V.K., Seliverstov A.A., Gerasimov Y.Y., Karvinen S., Välkky E. Comparison of Wood Harvesting Methods in Logging Companies of the Republic of Karelia. Working Papers of the Finnish Forest Research Institute 120. Joensuu, MELTA, 2009. 117 p. Available at: http://www.metla.fi/julkaisut/workingpapers/2009/mwp120.htm (accessed 01.03.20).

97. Terinov N.N., Gerts E.F., Bezgina Yu.N. Development of Logging Technology in the Urals. Lesnoy Zhurnal [Russian Forestry Journal], 2016, no. 2, pp. 81-90. DOI: https:// doi.org/10.17238/issn0536-1036.2016.2.81

98. Toivio J., Helmisaari H.-S., Palviainen M., Lindeman H., Ala-Ilomäki J., Sirén M., Uusitalo J. Impacts of Timber Forwarding on Physical Properties of Forest Soils in Southern Finland. Forest Ecology and Management, 2017, vol. 405, pp. 22-30. DOI: https://doi.org/10.1016/j.foreco.2017.09.022

99. Trubin D.V., Ipatov L.F., L’vov P.N., Trubin B.V., L’vov N.P., Klevtsov D.N. White Sea Taiga: Yesterday, Today, Tomorrow. Arkhangelsk, Pravda Severa Publ., 2015. 400 p.

100. Varfolomeev L.A. On Soil Formation in the Clear-Cuts of Spruce Forests in the Northern Part of the Middle Taiga Subzone. Pochvovedenie [Eurasian Soil Science], 1964, no. 8, pp. 15-25.

101. Vedrova E.F., Mukhortova L.V., Ivanov V.V., Krivobokov L.V., Boloneva M.V. Post-Logging Organic Matter Recovery in Forest Ecosystems of Eastern Baikal Region. Biology Bulletin, 2010, vol. 37, iss. 1, pp. 69-79. DOI: https://doi.org/10.1134/ $\underline{\mathrm{S} 1062359010010103}$

102. Wästerlund I. Strength Components in the Forest Floor Restricting Maximum Tolerable Machine Forces. Journal of Terramechanics, 1989, vol. 26, iss. 2, pp. 177-172. DOI: https://doi.org/10.1016/0022-4898(89)90005-0

103. Worrell R., Hampson A. The Influence of Some Forest Operations on the Sustainable Management of Forest Soils - A Review. Forestry, 1997, vol. 70, iss. 1, pp. 61-85. DOI: https://doi.org/10.1093/forestry/70.1.61

104. Wronski E.B., Murphy G. Responses of Forest Crops to Soil Compaction. Soil Compaction in Crop Production. Ed. by B.D. Soane, C. van Ouwerkerk. Amsterdam, Elsevier, 1994, pp. 317-342. DOI: https://doi.org/10.1016/B978-0-444-88286-8.50022-2

105. Zetterberg T., Olsson B.A., Löfgren S., von Brömssen C., Brandtberg P.-O. The Effect of Harvest Intensity on Long-Term Calcium Dynamics in Soil and Soil Solution at Three Coniferous Sites in Sweden. Forest Ecology and Management, 2013, vol. 302, pp. 280-294. DOI: https://doi.org/10.1016/j.foreco.2013.03.030

Вклад авторов: Все авторы в равной доле участвовали в написании статьи Authors' Contribution: All authors contributed equally to the writing of the article 